\title{
TEKNIK-TEKNIK REMEDIASI SEDIMEN TERKONTAMINASI LOGAM BERAT
}

\author{
Harmesa $^{1 *}$ \\ ${ }^{1}$ Pusat Penelitian Oseanografi, Lembaga Ilmu Pengetahuan Indonesia \\ Jl. Pasir Putih I, Ancol Timur, Jakarta Utara 14430 \\ *Alamat email: harmesa.ui@gmail.com
}

\begin{abstract}
Sediments are important in influencing changes and movements of the heavy metals in the aquatic environment. Heavy metals contamination of the sediments has negative ecological impacts on the environment. Therefore, economical, effective, and environmentally friendly remediation processes are needed. Purposes of the remediation are to reduce toxicity, bioavailability, and mobility of the metals from the polluted sediments. The remediations are developed using physical-chemical, biological and combination of both techniques. Physicalchemical techniques are carried out to decrease the stability of contaminated substances. Biological techniques or known as bioremediation are conducted through biological processes of plants, animals, and microorganisms. While the combination of both respective techniques, can produce maximum benefits and increase remediation efficiency.
\end{abstract}

Keywords: heavy metals, sediments, remediation.

\section{PENDAHULUAN}

Sedimen adalah bagian penting dari ekosistem akuatik. Sedimen memengaruhi proses transformasi dan transfer logam berat di lingkungan perairan. Kontaminasi sedimen oleh logam berat muncul sebagai isu lingkungan global semenjak tahun 1980-an. Keberadaan logam berat memberikan efek negatif pada lingkungan. Hal ini disebabkan karena logam berat tidak dapat terdegradasi, mengalami bioakumulasi (Saher \& Siddiqui, 2019) dan biomagnifikasi (Vandecasteele et al., 2004) serta bersifat toksik ketika melewati batas ambang tertentu (Rosado et al., 2016).

Logam berat masuk ke perairan melalui sumber alami dan sumber antropogenik. Sumber alami berupa pelapukan bebatuan dan aktivitas vulkanik, sedangkan sumber antropogenik terkait dengan aktivitas manusia seperti pelayaran, pertambangan, pertanian, industrialisasi, urbanisasi, limpasan air hujan dan limbah perkotaan (Duodu et al., 2017; Ke et al., 2017; Vu et al., 2017; Ismail et al., 2016). Di lingkungan air, logam berat terdistribusi dalam bentuk spesies terlarut, koloid, suspensi dan terikat dalam sedimen (Peng et al., 2009). Lebih dari $90 \%$ sumber antropogenik logam berat yang masuk ke lingkungan akuatik terakumulasi di dalam sedimen ( $\mathrm{Ra}$ et al., 2014) melalui proses adsorpsi, presipitasi, co-presipitasi dan biologis (Peng et al., 2018). Hal ini mengakibatkan konsentrasi logam berat di sedimen akan jauh lebih besar dibandingkan di badan air (Ansari et al., 2004).

Sedimen memengaruhi perubahan dan perpindahan logam berat secara signifikan di lingkungan (Peng et al., 2018). Dalam sedimen, logam berada dalam berbagai fraksi geokimia yaitu fase yang mudah tereduksi, organik, karbonat, residual, sulfida, oksida besi dan mangan (Qiant et al., 2009; Doni et al., 2015). 
Akumulasi logam berat dalam sedimen membahayakan bagi organisme di sekitarnya dengan menyebabkan turunnya keanekaragaman spesies, terganggunya pertumbuhan dan reproduksi hingga terjadinya kematian (Sfakianakis et al., 2014; Singh \& Kalamdhad, 2011). Ketika terjadi perubahan lingkungan secara fisikokimia (seperti perubahan $\mathrm{pH}$, potensial redoks dan oksigen terlarut), logam berat yang terakumulasi di sedimen akan terlarut ke badan air dan masuk ke rantai makanan (Peng et al., 2009; Peng et al., 2018) sehingga menimbulkan kerugian lingkungan dan meningkatkan risiko keterpaparan pada manusia ( $\mathrm{Fu}$ et al., 2013). Oleh karena itu, diperlukan proses remediasi terhadap sedimen yang terkontaminasi.

Proses remediasi memiliki setidaknya beberapa tujuan terkait pelarutan, pengendapan dan perubahan senyawa logam berat. Pelarutan terjadi untuk mengubah logam menjadi terlarut melalui pembentukan senyawa kompleks logam-EDTA (Shahid et al., 2014). Sementara pengendapan dilakukan dengan mengubah logam berat terlarut menjadi fase padatannya seperti logam hidroksida, logam karbonat, logam fosfat dan logam sulfida (Tsezos, 2009). Sedangkan perubahan senyawa logam berat dapat mengubah sifat logam dari zat yang berbahaya menjadi zat yang tidak berbahaya (Chen et al., 2015). Pada tulisan ini akan dipaparkan metode remediasi sedimen yang terkontaminasi logam berat, yaitu metode fisika-kimia, metode biologi dan metode gabungan. Masing-masing metode terdiri dari berbagai teknik remediasi. Tulisan ini diharapkan dapat menambah informasi dan pengetahuan pembaca mengenai teknik-teknik remediasi sedimen yang terkontaminasi logam berat.

\section{REMEDIASI SEDIMEN TERKONTA- MINASI LOGAM BERAT}

Logam berat yang bersifat toksik dapat dikurangi atau dihilangkan dari sedimen melalui proses remediasi. Menurut Peng et al., (2018), proses remediasi sedimen yang terkontaminasi logam berat dapat dikelompokkan menjadi tiga metode yaitu (1) metode fisika-kimia, seperti teknik capping, pencucian dan imobilisasi, (2) metode biologi, seperti teknik fitoremediasi dan bioaugmentasi; dan (3) metode gabungan.

\section{Metode Fisika-Kimia}

Metode remediasi secara fisika adalah proses penghentian kerusakan pada lingkungan menggunakan teknologi fisik dengan tujuan mengisolasi fisik, meningkatkan stabilitas zat yang terkontaminasi dan mengurangi imobilitas kontaminan. Sedangkan remediasi kimia dilakukan menggunakan pereaksi kimia dengan berbagai mekanisme reaksi untuk menghilangkan kontaminasi. Mekanisme yang terlibat adalah adsorpsi, katalisis, pertukaran ion, oksidasi dan reduksi (Song et al., 2017). Dalam aplikasinya, metode fisika dan kimia sering digabungkan untuk meningkatkan efisiensi remediasi, seperti metode capping, pencucian dan imobilisasi.

\section{Metode Capping}

Metode capping merupakan metode pemulihan sedimen dengan cara melapisi sedimen terkontaminasi dengan beberapa material. Tujuan dari metode ini adalah mengurangi kelarutan, mobilitas dan laju transfer logam berat dari sedimen (Knox et al., 2012). Metode capping diklasifikasikan menjadi dua jenis, yaitu passive capping dan active capping. Passive capping merupakan metode remediasi secara 
konvensional. Metode ini menciptakan penghalang untuk mengisolasi sedimen tercemar dengan lingkungan sekitarnya secara fisik, menstabilkan kontaminan di sedimen dan melepaskan kontaminan terlarut ke dalam air (Lee \& Park, 2013; Peng et al., 2018), seperti pada Gambar 1a. Material penutup sedimen terdiri dari (i) lapisan penstabil yang berfungsi memberikan stabilitas lokal pada sedimen asli, seperti geotekstil; (ii) lapisan isolasi untuk mengisolasi kontaminan dari lingkungan, seperti pasir; (iii) lapisan filter yang memberikan perlindungan hidrolik ke lapisan isolasi dasar, seperti kerikil; dan (iv) lapisan pelindung untuk melindungi filter dan lapisan isolasi dari erosi, seperti batu (Mohar et al., 2000; Peng et al., 2018).

Active capping merupakan metode alternatif yang menggunakan reaksi kimia antara material pelapis dengan kontaminan yang bukan hanya mencegah migrasi kontaminan ke dalam kolom air tetapi juga untuk menurunkan mobilitas, toksisitas dan bioavailabilitas kontaminan (Knox et al., 2012; Lee \& Park, 2013). Material yang digunakan adalah material yang reaktif untuk memperkuat kapasitas adsorpsi seperti kalsit, zeolit, karbon aktif, zerovalent iron, organoclay dan biopolimer (Zhang et al., 2016), seperti pada Gambar 1b. Metode capping dilaporkan oleh Knox et al., (2012) menggunakan senyawa aktif yang terdiri dari apatit, organoclay, biopolimer dan pasir untuk remediasi logam berat dari sedimen yang terkontaminasi. Efektivitas dari komposit ini dinilai dari penurunan bioavailabilitas kontaminan, ketahanan terhadap erosi dan dampak pada organisme bentik dalam rentang waktu 12 bulan. Selain itu, remediasi juga menggunakan senyawa aktif yang terdiri dari apatit, lempung, biopolimer dan zeolit. Campuran senyawa tersebut memiliki potensi tinggi untuk desain capping aktif yang ramah lingkungan dan efektif untuk perbaikan kontaminan logam $\mathrm{Co}, \mathrm{Cr}, \mathrm{Ni}$ dan $\mathrm{Pb}$ dengan mencegah transportasi difusi logam dari sedimen yang terkontaminasi selama 6 bulan. Capping aktif yang terdiri dari bahan-bahan tersebut dapat mengubah sifat kimia logam menjadi spesies logam yang relatif tidak bergerak sehingga mengurangi kemungkinan kontaminan logam berpindah dari sedimen ke dalam rantai makanan akuatik (Knox et al., 2014).

\section{Metode Pencucian}

Pencucian sedimen adalah teknologi remediasi ex situ yang relatif sederhana, yaitu dengan menambahkan larutan tertentu ke sedimen yang tercemar untuk memindahkan kontaminan dari sedimen ke larutan pencuci (Peng et al., 2009). Spesiasi logam berat yang terikat pada permukaan sedimen memainkan peran penting dalam efisiensi pencucian. Metode pencucian cocok digunakan untuk logam berat yang terikat secara lemah dengan partikel sedimen, seperti fraksi hidroksida, oksida dan karbonat (Chen et al., 2017; Mulligan et al., 2001). Metode pencucian umumnya digunakan untuk sedimen dengan partikel kasar, seperti pasir dan kerikil karena memiliki ikatan yang lemah dengan logam berat (Peng et al., 2009; Mohanty \& Mahindrakar, 2011).

Metode pencucian melalui dua tahapan yaitu, pelarutan logam dan pembuangan logam terlarut (Akcil et al., 2015). Larutan yang digunakan antara lain asam anorganik, asam organik, pengelat (Lasheen \& Amma, 2014) dan biosurfaktan (Chen et al., 2017) yang bertujuan untuk memfasilitasi pelarutan, penyebaran dan desorpsi kontaminan logam dari sedimen 


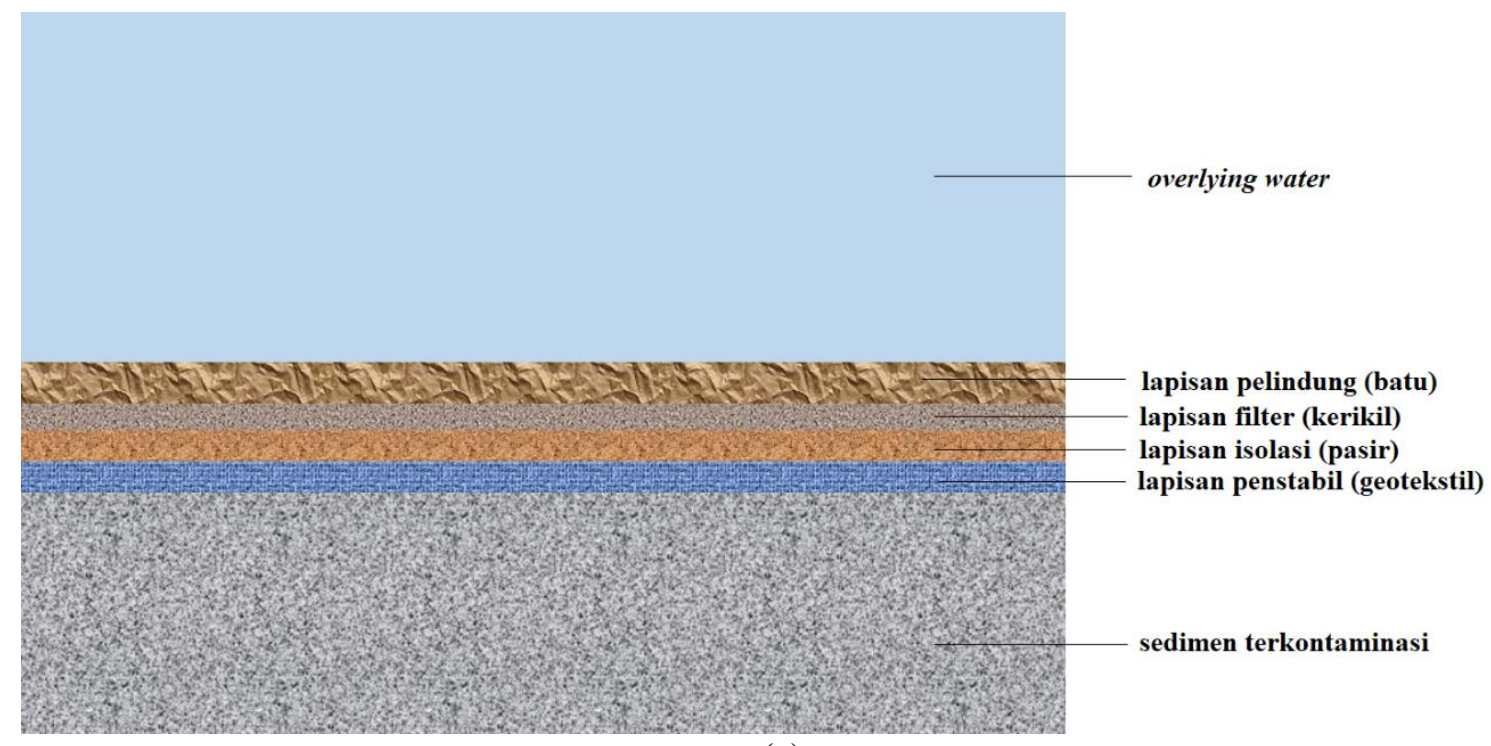

(a)

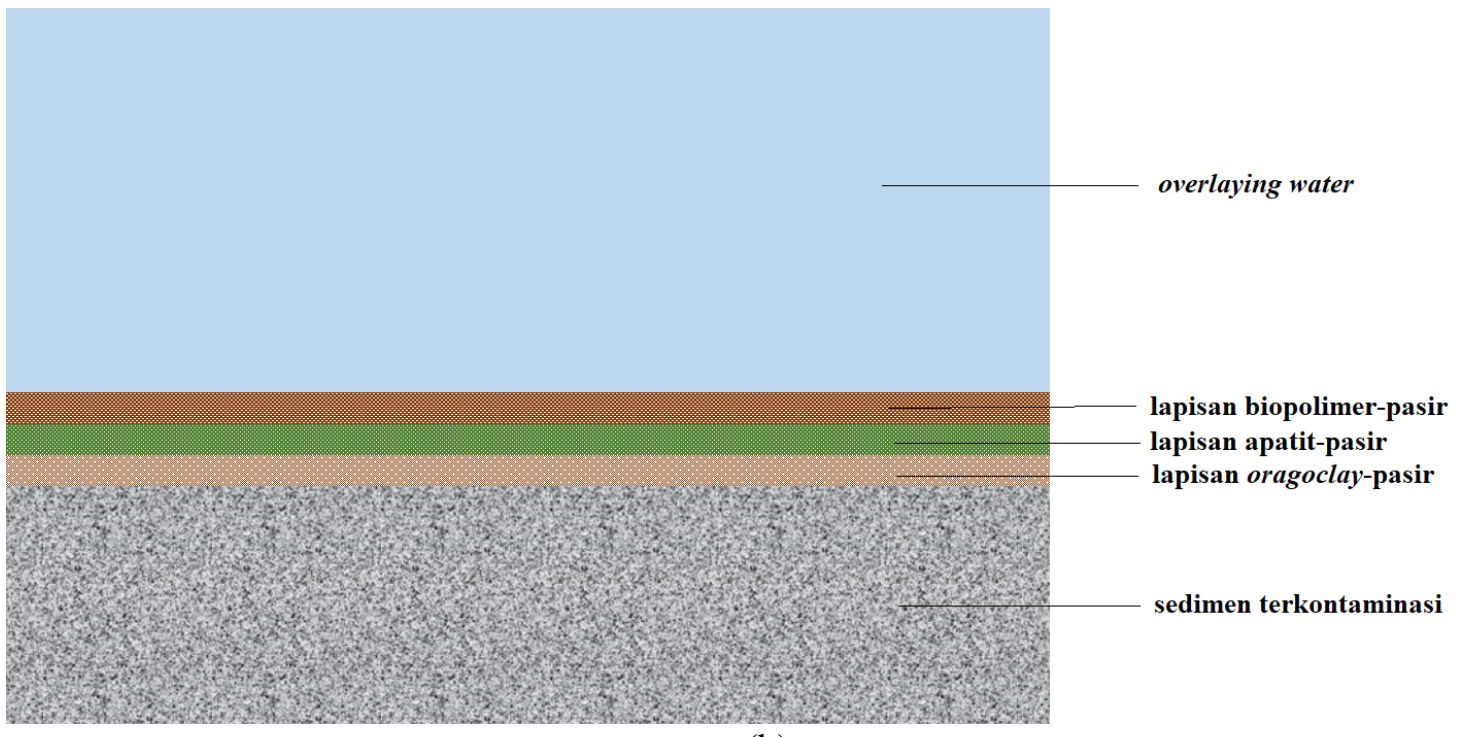

(b)

Gambar 1. Model pemulihan sedimen terkontaminasi dengan metode (a) capping aktif (modifikasi dari Peng et al., 2018) dan (b) capping pasif (modifikasi dari Knox et al., 2014).

tercemar (Peng et al., 2018). Metode pencucian yang dikembangkan oleh Lasheen \& Amma (2014) menggunakan senyawa EDTA untuk mengekstrak logam $\mathrm{Pb}$ dan $\mathrm{Cd}$ dari sedimen terkontaminasi.

Efisiensi pembuangan timbal mencapai $72,54 \%$ dan kadmium 53,58\% pada kondisi optimum. Senyawa pengelat seperti EDTA secara efektif memperbaiki sedimen yang terkontaminasi logam berat dengan membentuk senyawa kompleks (Yoo et al., 2013) sehingga ikatan kuat yang terjadi antara ligan-metal mampu meningkatkan efisiensi ekstraksi logam dari sedimen. Sedangkan Chen et al., (2017) menggunakan rhamnolipid sebagai agen pencuci sedimen terkontaminasi logam berat dengan efisiensi mencapai $86,67 \%$ untuk $\mathrm{Cd}, 80,21 \%$ untuk $\mathrm{Cu}$, $63,54 \%$ untuk $\mathrm{Pb}$ dan $47,85 \%$ untuk $\mathrm{Cr}$. Ikatan antara logam dan permukaan sedimen berdampak pada efisiensi pencucian dan urutan pencucian. $\mathrm{Cd}$ dan $\mathrm{Cu}$ terikat lemah dengan sedimen sehingga lebih mudah dihilangkan dibandingkan $\mathrm{Pb}$ dan $\mathrm{Cr}$. 


\section{Metode Imobilisasi}

Metode imobilisasi dikenal juga sebagai metode stabilisasi yang bertujuan untuk mengubah logam menjadi bentuk baru dalam fase yang tidak mudah larut sehingga lebih stabil di lingkungan (Qian et al., 2009). Imobilisasi digunakan untuk remediasi sedimen tercemar secara in situ atau ex situ melalui proses ekstraksi logam berat, meskipun tidak dapat menghilangkan logam dari sedimen (Peng et al., 2009). Metode ini mengurangi solubilitas, mobilitas dan bioavailabilitas logam dengan mengubah spesies kimianya melalui proses pertukaran ion, adsorbsi, oksidasi, reduksi dan presipitasi (Peng et al., 2018; Qian et al., 2009). Agen penstabil dapat berupa zat anorganik, zat organik atau senyawa kompleks yang memiliki kapasitas pertukaran kation yang tinggi, ramah lingkungan dan murah seperti lumpur merah dan arang besi, oksida besi atau hidroksida besi, zeolit, sepiolit, apatit, nano material dan karbon aktif (Yin \& Zhu, 2016). Kestabilan logam berat yang terbentuk nantinya akan dipengaruhi oleh karakteristik sedimen, tipe zat, konsentrasi logam, waktu remediasi serta metode remediasi (Peng et al., 2018). Proses remediasi logam berat dengan metode imobilisasi dapat dilihat pada ilustrasi Gambar 2.

Huang et al., (2016) menggunakan senyawa S-NZVI (sodium alginate-nano zero valent iron) untuk imobilisasi logam $\mathrm{Cd}$ dengan meningkatkan fraksi residualnya dan menurunkan bioavailabilitas $\mathrm{Cd}$ di sedimen. Yin \& Zhu, (2016) menggunakan mineral lempung kaya kalsium untuk remediasi $\mathrm{Pb}$ dan $\mathrm{Cd}$ dari sedimen dengan membentuk ikatan kimia yang kuat melalui mekanisme kompleksasi permukaan dan pengendapan. Chen et al., (2015) melaporkan penggunaan senyawa nano zero valen iron/activated carbon (nZVI/AC) sebagai senyawa penstabil dari logam $\mathrm{Cu}, \mathrm{Pb}, \mathrm{Cd}$ dan $\mathrm{Cr}$ yang berasal dari sedimen tercemar. Hasil penelitian menunjukkan bahwa penambahan nZVI/AC dalam bentuk partikel bubuk dengan ukuran 0,075-0,18 mm memiliki kemampuan stabilitas yang lebih efektif dari pada bentuk granularnya.

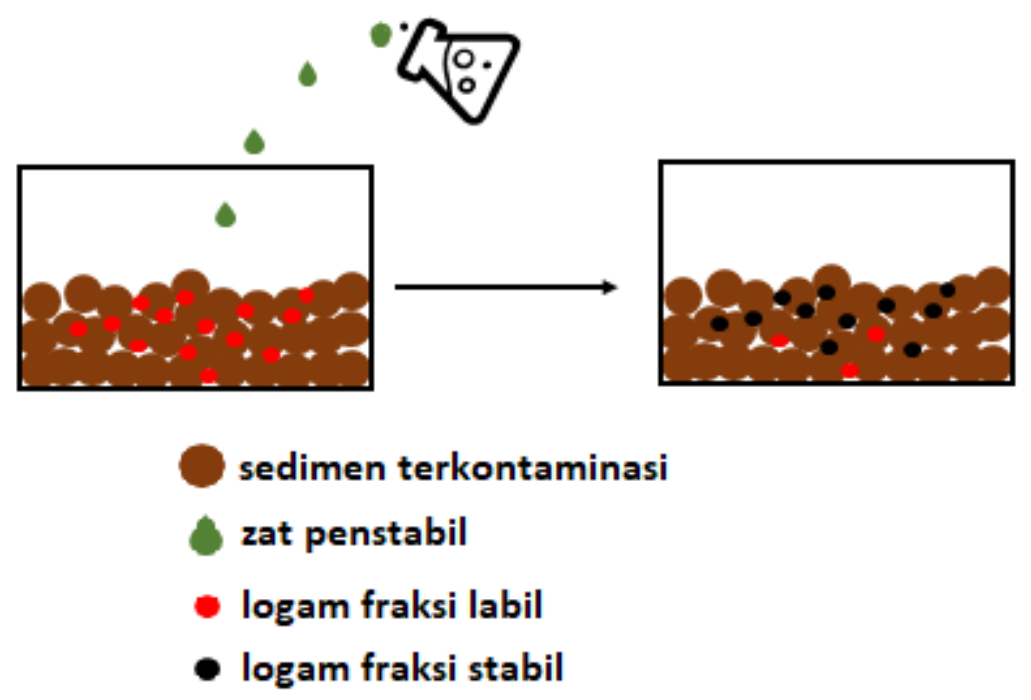

Gambar 2. Metode imobilisasi logam berat dengan metode imobilisasi (modifikasi dari Wang et. al., 2018). 
Senyawa nZVI/AC mampu mengubah ikatan logam berat yang relatif lemah menjadi lebih kuat sehingga mengurangi bioavailabilitas dan toksisitasnya. Shin et al., (2015) menggunakan lumpur merah sebagai zat penstabil. Hasilnya menunjukkan bahwa komponen tersebut memberikan efek terbaik dalam mengendalikan bioavailabilitas dan toksisitas logam berat ( $\mathrm{Zn}$ dan $\mathrm{Ni}$ ) dalam sedimen laut yang terkontaminasi.

Zhang et al., (2010) menggunakan partikel nano-hidroksiapatit (nHAp) dalam proses imobilisasi $\mathrm{Pb}$ dan $\mathrm{Cd}$ untuk pemulihan sedimen tercemar. Partikel nHAp dapat memobilisasi logam berat dalam sedimen secara efektif dengan meningkatkan fraksi residual melalui mekanisme pelarutan-pengendapan untuk imobilisasi $\mathrm{Pb}$ dan mekanisme kompleksasi permukaan berikut difusi intrapartikel untuk imobilisasi Cd. Wan et al., (2018) menggunakan Rha-nClAP (rhamnolipid nano-chlorapatite) untuk meningkatkan efisiensi imobilisasi $\mathrm{Pb}$ dan $\mathrm{Cd}$ dengan mengubah logam dari fraksi labil menjadi fraksi stabil melalui proses pengendapan dan adsorpsi. Rha bertindak sebagai eluen untuk melepaskan logam dari sedimen, sedangkan nClAP bertindak sebagai agen pengendap sehingga mampu meningkatkan efisiensi kestabilan logam.

\section{Metode Biologi}

Metode remediasi dengan teknik biologi dikenal sebagai proses bioremediasi. Bioremediasi diterapkan untuk menghilangkan kontaminasi lingkungan melalui proses biologis oleh tumbuhan, hewan dan mikroorganisme (Song et al., 2017). Selama proses bioremediasi, terjadi perubahan tingkat oksidasi logam berat melalui pembentukan senyawa organik kompleks. Perubahan tingkat oksidasi dapat menurunkan sifat toksisitas dan bioavailabilitas dari logam berat. Pembentukan senyawa organik kompleks yang mudah menguap dan mudah larut dalam air dapat dihilangkan melalui proses leaching. Sementara pembentukan senyawa organik kompleks yang sukar larut dalam air dapat dihilangkan melalui proses pengendapan (Chibuike \& Obiora, 2014). Metode bioremediasi yang banyak dikembangkan adalah fitoremediasi dan bioaugmentasi.

\section{Fitoremediasi}

Metode fitoremediasi merupakan teknologi yang melibatkan penggunaan tanaman untuk menghilangkan polutan dari lingkungan, karena tanaman memiliki kemampuan menyerap dan mengakumulasi logam berat dalam konsentrasi yang tinggi di akar (Kumar et al., 2008). Fitoremediasi merupakan metode yang ekonomis, hemat energi, ramah lingkungan dan dapat diterapkan pada area yang luas untuk pemulihan lingkungan dari kontaminan logam berat (Sakakibara et al., 2011; Tangahu et al., 2011).

Metode remediasi untuk logam berat yang berbasis pada tumbuhan fokus pada proses fitoekstraksi dan fitostabilisasi (Doni et al., 2015). Fitoekstraksi merupakan proses biokimia yang penting di tumbuhan, yaitu proses penyerapan logam berat dari sedimen terkontaminasi melalui akar atau tunas, selanjutnya logam berat tersebut dipindahkan ke batang dan daun. Jumlah logam yang terakumulasi di akar umumnya lebih banyak dan berbeda signifikan dibandingkan yang terakumulasi di batang dan daun (Kumar et al., 2008). Efisiensi fitoekstraksi bergantung pada 
bioavailabilitas logam berat, spesiasi logam berat dan spesies tanaman (Peng et al., 2018). Sedangkan proses fitostabilisasi menggunakan eksudat yang dihasilkan oleh akar untuk menstabilkan, mendemobilisasi dan mengurangi bioavailabilitas logam berat (Tangahu et al., 2011). Salah satu bentuk eksudat tanaman adalah fulvic acid yang dihasilkan oleh akar tanaman mangrove Avicennia marina yang mampu mengubah ion logam menjadi bentuk kompleks dan bersifat stabil (Zhu et al., 2019).

Tanaman yang ideal untuk fitoremediasi adalah tanaman yang memiliki kemampuan untuk mengakumulasi logam berat, kemampuan untuk memindahkan logam berat dari akar ke daun, kemampuan mentoleransi toksisitas logam berat, kemampuan untuk beradaptasi dengan kondisi lingkungan dan iklim yang berlaku (Doni et al., 2015), ketahanan terhadap patogen dan hama, mudah dalam budidaya dan panen, dan tidak disukai herbivora untuk menghindari kontaminasi rantai makanan (Peng et al., 2018; Ali et al., 2013). Tanaman yang banyak digunakan untuk remediasi logam berat adalah tumbuhan mangrove, seperti Avicennia marina, Lumnitzera racemosa, Bruguiera gymnorrhiza, Bruguiera parvilora, Ceriops tagal, Sonneratia caseolaris, Rhizophora apiculata, Rhizophora mangle, Laguncularia racemosa, Avicennia germinans, Avicennia alba, Acanthus ilicifolius (MacFarlane et al., 2003, Analuddin et al., 2017, Lewis et al., 2011, Hamzah \& Setiawan, 2010, Wang et al., 2012, Kamaruzzaman et al., 2009, Maldonando-Roman et al., 2016, Rahman et al., 2019, Kaewtubtim et al., 2016; Chowdhury et al., 2015) dan tumbuhan lamun seperti Zostera marina, Cymodocea rotundata, Thalasia hemprichii,
Syringodium isoetifolium (Lee et al., 2019; Paz-Alberto \& Sigua, 2015).

Tumbuhan laut yang berperan dalam proses fitoremediasi tidak hanya mangrove dan lamun, tetapi juga mikroalga dan makroalga. Pengunaan mikroalga dan makroalga mendapat perhatian besar karena kemampuannya untuk menyerap logam dan mengambil unsur toksik dari lingkungan atau menjadikannya kurang berbahaya (Chekroun \& Baghour, 2013). Selain itu, penggunaan mikroalga dalam proses remediasi banyak dilakukan karena biaya pertumbuhan yang tidak mahal dan teknik yang ramah lingkungan. Efisiensi pembuangan logam berat oleh mikroalga bergantung pada jenis mikroalga, sifat dan konsentrasi ion logam, dan waktu kulturnya.

Kwon et al., (2017) menggunakan empat spesien mikroalga untuk proses remediasi sedimen laut dari logam kontaminan $\mathrm{Cu}$ dan $\mathrm{Zn}$, yaitu Phaeodactylum tricornutum, Nitzchia sp., Skeletonema sp. dan Chlorella vulgaris. Mikroalga ditempatkan di dalam tube membran semi-permeable yang terhubung dengan LED untuk mendapatkan pertumbuhan yang optimal. Hasilnya menunjukkan bahwa Chlorella vulgaris merupakan spesies yang paling efisien untuk proses fitoremediasi logam berat dibandingkan mikroalga lainnya. Proses adsorpsi dan absorpsi merupakan proses yang paling dominan untuk pembuangan logam berat dari sedimen laut oleh spesies mikroalga.

Cameron et al., (2018) melaporkan penggunaan Tetraselmis marina AC16MESO untuk remediasi sedimen tercemar logam berat dengan mengevaluasi efisiensi sedimentasi dan efisiensi pembuangan logam berat. Efisiensi sedimentasi mencapai $95,6 \%$ setelah 5 jam dekantasi 
dan efisiensi pembuangan logam berat mencapai $40-90 \%$ untuk $\mathrm{Cu}^{2+}, 100 \%$ untuk $\mathrm{Fe}^{3+}$ dan 20-50 \% untuk $\mathrm{Mn}^{2+}$ setelah periode 72 jam untuk rentang konsentrasi 1,0-5,0 $\mathrm{mgL}^{-1}$. Tetraselmis marina menjadi kandidat yang menjanjikan untuk proses bioremediasi karena toleran terhadap keberadaan logam berat, efisiensi pembuangan logam yang tinggi dan waktu proses yang singkat.

\section{Bioaugmentasi}

Bioaugmentasi adalah proses bioremediasi yang dilakukan dengan cara menambahkan mikroorganisme ke dalam sedimen terkontaminasi dengan meningkatkan aktivitas biologisnya untuk mendegradasi dan mempercepat penghilangan logam berat (Song et al., 2017). Mikroorganisme yang dipilih harus mampu beradaptasi dengan lingkungan terkontaminasi dan memiliki kemampuan katabolik spesifik untuk menurunkan kontaminan target (Perelo, 2010). Kontaminan logam berat tidak dapat langsung terdegradasi menjadi senyawa yang tidak berbahaya (Akcil et al., 2015). Namun, mikroorganisme seperti bakteri dapat mengubah bentuk kimia, mobilitas, toksisitas, dan bioavailabilitas logam berat melalui proses metabolisme. Interaksi antara sel bakteri dan logam berat terjadi melalui biosorpsi, bioakumulasi, bioasimilasi, biopresipitasi, bioleaching, biodegradasi, biosintesis, dan biotransformasi (Peng et al., 2018) seperti pada Gambar 3.

Interaksi penting dalam bioaugmentasi antara mikroorganisme yang memengaruhi toksisitas dan transportasi logam berat adalah biosorpsi, bioakumulasi dan biotransformasi. Biosorpsi adalah asosiasi logam berat terlarut dengan permukaan sel melalui proses kompleksitas, pengkelatan, reduksi, pengendapan atau pertukaran kation/anion, sehingga toksisitas logam berat dapat dikurangi. Bioakumulasi adalah retensi dan konsentrasi zat dalam mikroorganisme. Zat terlarut dari luar sel masuk melalui membran seluler dan terakumulasi di sitoplasma. Biotransformasi mengubah bentuk kimia dari logam berat, termasuk mobilitas, toksisitas dan biovailabilitasnya (Peng et al., 2018; Tabak et al., 2005).

Untuk remediasi sedimen, teknik bioaugmentasi yang dikembangkan adalah biomobilisasi dan bioimobilisasi. Biomobilisasi digunakan secara luas untuk remediasi logam berat di sedimen tercemar. Proses ini meliputi dua tahap yaitu (i) logam berat dilepaskan ke larutan melalui metode biologi dan (ii) logam berat terlarut dipisahkan ke dalam fase padat dan likuid (Peng et al., 2018).

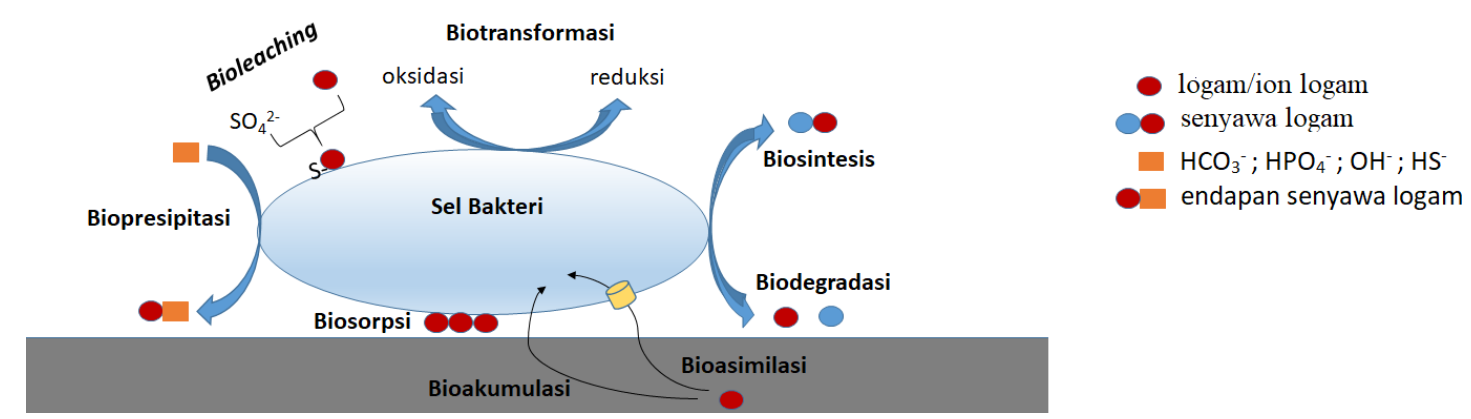

Gambar 3. Proses bioremediasi logam berat menggunakan sel bakteri (modifikasi dari Peng et al., 2018). 
Logam berat tidak dapat terdegradasi, tetapi dapat berubah melalui proses biogeokimia, yaitu perubahan mobilitas, toksisitas dan bioavailabilitasnya. Bioleaching adalah salah satu pendekatan yang paling umum untuk biomobilisasi, karena menggunakan efek oksidasi biologis dan produksi asam amino untuk mengubah senyawa logam tidak larut menjadi senyawa ion terlarut. Metode bioleaching yang dilaporkan oleh Akinci et al., (2011) dan Nguyen et al., (2015) menggunakan kultur bakteria Acidithiobacillus spp. Efisiensi remediasi logam $\mathrm{Pb}$ mencapai $>80 \%$ untuk Acidithiobacillus thiooxidans dan $63 \%$ untuk Acidithiobacillus ferrooxidans, sedangkan efisiensi untuk $\mathrm{Mn}$ dan $\mathrm{Zn}$ lebih bagus menggunakan Acidithiobacillus ferrooxidans.

Beolchini et al., (2009) menggunakan campuran bakteria autotrofik (Acidithiobacillus thiooxidans, Acidithiobacillus ferrooxidans, Leptospirillum ferrooxidans) dan bakteria heterotropik (Acidiphilium cryptum) untuk remediasi sedimen tercemar. Hasilnya menunjukkan efisiensi mobilisasi logam berat meningkat signifikan dan mencapai > 90\% untuk logam $\mathrm{Cu}, \mathrm{Cd}, \mathrm{Hg}, \mathrm{Zn}$ dan tidak bergantung pada keberadaan sulfur. Zhu et al., (2014) melaporkan penggunaan bakteria autotrofik $A$. thiooxidans dan bakteria heterotrofik Pseudomonas aeruginosa dengan efisiensi remediasi mencapai $95,2 \%, 94,2 \%, 90,1 \%$ dan $84.4 \%$ untuk logam $\mathrm{Zn}, \mathrm{Mn}, \mathrm{Cu}$ dan $\mathrm{Cd}$.

Sedangkan metode bioimobilisasi pada bioaugmentasi mengacu pada penggunaan mikroorganisme untuk mengubah senyawa logam toksik menjadi tidak toksik melalui proses biosorpsi, bioakumulasi, biopresipitasi dan biotransformasi (Peng et al., 2018). Mikroorganisme anaerob yang banyak dikembangkan untuk proses bioimobilisasi adalah Sulphate Reducing Bacteria (SRB). SRB mampu mereduksi sulfat menjadi hidrogen sulfida yang mudah bereaksi dengan logam membentuk endapan yang stabil (Li et al., 2016). Tujuan metode ini adalah menurunkan kelarutan, mobilitas, bioavailabilitas dan toksisitas logam berat tanpa melepaskannya dari sedimen tercemar dalam bentuk logam sulfida (Peng et al., 2018b).

Peng et al., (2019) mempelajari analisis mikrobiologi sedimen terkontaminasi $\mathrm{Cd}$ dengan bioimobilisasi SRB. Selama proses biostabilisasi, terjadi perubahan komunitas bakteri secara signifikan di sedimen. Kehadiran Bacillaceae dan Streptococcaceae mengurangi biostabilisasi $\mathrm{Cd}$ karena menghambat aktivitas biologi SRB. Sedangkan keberadaan Nitrospinaceae dan Nitrospira mampu menghambat proses denitrifikasi sehingga memberikan efek positif pada aktivitas SRB untuk mereduksi sulfat sehingga mempermudah proses biostabilisasi Cd. Park et al., (2008) melaporkan penggunaan mikroorganisme Ralstonia sp. HM-1 dengan peningkatan alkalinitas yang dihasilkan dari reduksi sulfat oleh SRB yang mampu menghilangkan kadmium dan seng dengan efisiensi mencapai 99,7\% setelah 35 hari. Sedangkan Li et al., (2016) mengimobilisasi SRB dalam bentuk butiran dengan PVA memberikan hasil yang lebih efektif untuk mengubah logam berat menjadi fase terikat yang stabil. Efisiensi penghilangan logam $\mathrm{Cu}, \mathrm{Zn}, \mathrm{Pb}$ dan $\mathrm{Cd}$ mencapai $76,3 \%, 95,6 \%, 100 \%$ dan $91,2 \%$ berturut-turut. Keuntungan dari metode bioaugmentasi adalah aman, mudah, efektif, biaya rendah, dapat dikerjakan onsite dan dapat digabung dengan perlakuan kimia atau fisika. Sedangkan 
kelemahannya adalah butuh waktu yang lama dan aplikasi terbatas, serta sulit memprediksi dampak bioremediasinya.

\section{Metode Gabungan}

Metode fisika-kimia dikenal sebagai teknologi tradisional yang memiliki efisiensi yang tinggi untuk proses remediasi namun membutuhkan biaya yang besar. Sedangkan metode biologi merupakan metode yang menjanjikan karena ramah lingkungan, namun membutuhkan waktu yang lama dan tidak stabil dalam efisiensinya. Sehingga penggabungan dari kedua metode tersebut dapat meningkatkan efesiensi remediasi dengan konsumsi energi yang rendah (Peng et al., 2018; Song et al., 2017).

Penelitian yang dilakukan oleh Bianchi et al., (2009) dengan pendekatan berbasis ekosistem bertujuan untuk menguji efisiensi teknik fitoremediasi yang diterapkan pada sedimen laut yang terkontaminasi logam berat di pelabuhan Livorno, Italia. Metode yang diterapkan melibatkan penggunaan tanaman Paspalum vaginatum dan Tamarix gallica dengan cacing tanah (Eisenia foetida sp.). Penggabungan tersebut menciptakan kembali ekosistem aktif dengan adanya interaksi antara tanaman, mikroorganisme dan makroorganisme. Proses ekstraksi logam berat dipelajari dengan melihat perbandingan jumlah logam berat di tunas dan di akar. Hasil penelitian menunjukkan bahwa rasio jumlah logam berat Ni dari PL (Tanaman Paspalum vaginatum dan Tamarix gallica + cacing tanah Eisenia foetida sp.) dan $\mathrm{P}$ (Tanaman Paspalum vaginatum dan Tamarix gallica) adalah 1,5:1,1. Hasil tersebut memperlihatkan bahwa ekstraksi logam berat $\mathrm{Ni}$ yang dihasilkan dari penggabungan tanaman dan cacing tanah lebih tinggi dibandingkan dengan hanya menggunakan tanaman.

Doni et al., (2015) melaporkan penggunaan dua jenis tanaman yang berasosiasi ( $P$. vaginatum $S w .+T$. gallica $L$. dan $P$. vaginatum $S w .+S$. junceum $L$.) yang disertai dengan penambahan pupuk kompos untuk meningkatkan efisiensi fitoremediasi logam berat dari sedimen laut yang terkontaminasi. Sinergi dari tanaman dan pupuk kompos mampu meningkatkan kapasitas rhizosfer untuk mengendapkan logam berat. Asosiasi $P$. vaginatum $S w$. dan T. gallica L. menunjukkan efisiensi akumulasi yang lebih tinggi untuk logam $\mathrm{Zn}$ dan $\mathrm{Ni}$, sedangkan asosiasi $P$. vaginatum $S w$. dan $S$. junceum $L$. menunjukkan efisiensi akumulasi yang lebih tinggi untuk logam $\mathrm{Cu}$ dan $\mathrm{Pb}$.

Teknik fitoekstraksi dengan penambahan agen pengompleks digunakan untuk remediasi sedimen laut yang terkontaminasi logam berat secara ex situ. Agen pengompleks logam seperti EDTA atau EDDS digunakan untuk mengaktivasi logam berat selama proses fitoekstraksi (Peng et al., 2018). Selanjutnya tanaman dengan laju pertumbuhan yang tinggi dan biomassa yang besar digunakan untuk mengekstrak logam berat sehingga efisiensi logam berat meningkat. Bianchi et al., (2008) menggunakan $P$. vaginatum spp. dengan penambahan agen pengelat (EDTA, asam sitrat dan humic substances) untuk meningkatkan proses fitoekstraksi logam $\mathrm{Cu}$ dan $\mathrm{Zn}$ dari sedimen laut yang tercemar. Hasilnya menunjukkan penggunaan EDTA (480 mg/l) mampu meningkatkan mobilisasi logam $\mathrm{Cu}$ dan $\mathrm{Zn}$ dari sedimen sebesar $58 \%$ dari total $\mathrm{Cu}$ dan $50 \%$ dari total Zn. Penggunaan humic substances $(1.000 \mathrm{mg} / \mathrm{l})$ menunjukkan peningkatan mobilisasi logam dari sedimen sebesar $32 \%$ dari total $\mathrm{Cu}$ dan $5 \%$ dari total $\mathrm{Zn}$, 
sedangkan penggunaan asam sitrat tidak memberikan efek yang signifikan.

Sistem terintegrasi dari micro zero valent iron $\left(\mathrm{mFe}^{0}\right)$ dan sulfate reducing bacteria (SRB) digunakan oleh Li et al., (2016) untuk mengolah sedimen terkontaminasi logam berat. Hasil penelitian menunjukkan bahwa efisiensi remediasi oleh $\mathrm{mFe}^{0} / \mathrm{SRB}$ berkisar antara 90,69\% sampai 100\% untuk logam $\mathrm{Cu}, \mathrm{Cd}$, $\mathrm{Zn}$ dan $\mathrm{Pb}$. Endapan logam-logam tersebut ditemukan dalam bentuk fraksi mineral stabil, yaitu fraksi teroksidasi dan fraksi residu. Kelebihan $\mathrm{mFe}^{0} / \mathrm{SRB}$ terletak pada dua hal, yaitu (1) $\mathrm{mFe}^{0}$ mampu merangsang aktivitas SRB, (2) senyawa besi yang berasal dari $\mathrm{mFe}^{0}$ dan metabolit dari SRB (senyawa sulfida, sulfit dan tiosulfat) bergabung dengan fraksi logam berat yang dimobilisasi sehingga membentuk fraksi yang lebih stabil.

\section{PENUTUP}

Berbagai penelitian menunjukkan bahwa sedimen yang terkontaminasi logam berat dapat dipulihkan dengan teknik remediasi. Teknik-teknik remediasi yang dikembangkan didasarkan pada metode fisika-kimia, metode biologi dan metode gabungan. Metode fisika-kimia menggunakan teknik secara fisik disertai dengan reaksi kimia dari zat yang digunakan, seperti teknik capping, pencucian dan imobilisasi. Metode biologi dikenal dengan proses bioremediasi yang menggunakan tanaman (metode fitoremediasi) dan mikroorganisme (bioaugmentasi). Sedangkan metode gabungan merupakan penggabungan dari metode fisika-kimia dan fitoremediasi, metode fisika-kimia dan bioaugmentasi serta fitoremediasi dan bioaugmentasi dengan tujuan mendapatkan efisiensi remediasi yang tinggi.

\section{UCAPAN TERIMA KASIH}

Ucapan terima kasih saya sampaikan kepada Ibu Lestari dan Bapak Fitri Budiyanto atas saran dan masukan selama penulisan artikel ini.

\section{DAFTAR PUSTAKA}

Akcil, A., Erust, C., Ozdemiroglu, S., Fonti, V., \& Beolchini, F. (2015). A Review of approaches and techniques used in aquatic contaminated sediments: metal removal and stabilization by chemical and biotechnological processes. Journal Cleaner Production, 86: 24-36.

Akinci, G., \& Guven, D.E. (2011). Bioleaching of heavy metals contaminated sediment by pure and mixed cultures of Acidithiobacillus spp. Desalination, 268(1-3): 221226.

Ali, H., Khan, E., \& Sajad, M.A. (2013). Review: Phytoremediation of heavy metals-Concepts and applications. Chemosphere, 91(7): 869-881.

Analuddin, K., Sharma, S., Jamili, Septiana, A., Sahidin, I., Rianse, U., \& Nadaoka, K. (2017). Heavy metal bioaccumulation in mangrove ecosystem at the coral triangle ecoregion, Southeast Sulawesi, Indonesia. Marine Pollution Bulletin, 125(1-2): 472-480.

Ansari, T.M., Marr, I.L. \& Tariq, N. (2004). Heavy metals in marine pollution perspective-A mini review. Journal of applied sciences, 4: 1-20

Beolchini, F., Dell'Anno, A., Propis, L.D., Ubaldini, S., Cerrone F., \& Danovaro, R. (2009). Auto- and heterotrophic acidophilic bacteria enhance the bioremediation efficiency of sediments contaminated by heavy metals. Chemosphere, 74(10): 1321-1326. 
Bianchi, V. \& Masciandaro, G. (2009). Phytoremediation and bio-physical conditioning of dredged marine sediments for their re-use in the environment. Water, Air, \& Soil Pollution, 210(1-4):187-195.

Bianchi, V., Masciandaro, G., Giraldi, D., Ceccanti B., \& Ianelli, R. (2008). Enhanced heavy metal phytoextraction from marine dredged sediments comparing conventional chelating agents (citric acid and EDTA) with humic substances. Water, Air, and Soil Pollution, 193(14): 323-333.

Cameron, H., Mata, M.T., \& Riquelme, C. (2018). The effect of heavy metals on the viability of Tetraselmis marina AC16MESO and an evaluation of the potential use of this microalga in bioremediation. PeerJ, 6:e5295.

Chekroun, K.B. \& Baghour, M. (2013). The role of algae in phytoremediation of heavy metals: A review. J. Mater. Environmental Science, 4(6): 873880.

Chen W., Qu, Y., Xu, Z., He, F., Chen, Z., Huang S., \& Li, Y. (2017). Heavy metal $(\mathrm{Cu}, \mathrm{Cd}, \mathrm{Pb}, \mathrm{Cr})$ washing from river sediment using biosurfactant rhamnolipid. Environmental Science and Pollution Research, 24(19): 16344-16350.

Chen, W.F., Zhang, J., Zhang, X., Wang, W., \& Li, Y. (2015). Investigation of heavy metal $(\mathrm{Cu}, \mathrm{Pb}, \mathrm{Cd}$ and $\mathrm{Cr})$ stabilization in river sediment by nano-zero-valent iron/activated carbon composite. Environmental Science and Pollution Research, 23(2): 1460-1470.

Chibuike, G.U., \& Obiora, S.C. (2014). Heavy metal polluted soils: effect on plants and bioremediation methods. Applied and Environmental Soil Science, 2014: 1-12.

Chowdhury, R., Favas, P.J.C., Pratas, J., Jonathan, M.P., Ganesh, P.S., \& Sarkar, S.K. (2015). Accumulation of trace metals by mangrove plants in
Indian Sundarban Wetland: Prospects for Phytoremediation. International Journal of Phytoremediation, 17(9): 885-894.

Doni, S., Macci, C., Peruzzi, E., Iannelli, R., \& Masciandaro, G. (2015). Heavy metal distribution in a sediment phytoremediation system at pilot scale. Ecological Engineering, 81: 146-157.

Duodu, G.O., Goonetilleke, A., \& Ayoko, G.A. (2017). Potential bioavailability assessment, source apportionment and ecological risk of heavy metals in the sediment of Brisbane River estuary, Australia. Marine Pollution Bulletin, 117(1-2): 523-531.

Fu, J., Hu, X., Tao, X., Yu, H., \& Zhang, Z. (2013). Risk and toxicity assessments of heavy metals in sediments and fishes from the Yangtze River and Taihu Lake, China. Chemosphere, 93(9): 1887-1895.

Hamzah, F., \& Setiawan, A. (2010). Akumulasi logam berat $\mathrm{Pb}, \mathrm{Cu}$ dan Zn di Hutan Mangrove Muara Angke, Jakarta Utara. Jurnal Ilmu dan Teknologi Kelautan Tropis, 2: 41-52.

Huang, D., Xue, W., Zeng, G., Wan, J., Chen, G., Huang, C., Zhang, C., Cheng, M., \& Xu, P. (2016). Immobilization of $\mathrm{Cd}$ in river sediments by sodium alginate modified nanoscale zerovalent iron: Impact on enzyme activities and microbial community diversity. Water Research, 106: 15-25.

Ismail, A., Toriman, M.E., Juahir, H., Zain, S.M., Habir, N.L.A., Retnam, A., Kamaruddin, M.K.A., Umar, R \& Azid, A. (2016). Spatial assessment and source identification of heavy metals pollution in surface water using several chemometric techniques. Marine Pollution Bulletin, 106(1-2): 292-300.

Kaewtubtim, P., Meeinkuirt, W., Seepom, S., \& Pichtel, J. (2016). Heavy metal phytoremediation potential of plant species in a mangrove ecosystem in 
Pattani Bay, Thailand. Applied Ecology and Environmental Research, 14(1): 367-382.

Kamaruzzaman, B.Y., Ong, M.C., Jalal, K. C.A., Shahbudin, S., \& Nor, O.M. (2009). Accumulation of lead and copper in Rhizophora apiculata from Setiu mangrove forest, Terengganu, Malaysia. Journal of Environmental Biology, 30(5): 821-824.

Ke, X., Gui, S., Huang, H., Zhang, H., Wang, C., \& Guo, W. (2017). Ecological risk assessment and source identification for heavy metals in surface sediment from the Liaohe River protected area, China. Chemosphere, 175: 473-481.

Knox, A.S., Paller, M.H., \& Roberts, J. (2012). Active capping technologynew approaches for in situ remediation of contaminated sediments. Remediation Spring, 22(2): 93-117.

Knox, A.S., Paller. M.H., \& Dixon, K. L. (2014). Evaluation of active cap materials for metal retention in sediments. Remediation Spring, 24(3): 49-69.

Kumar, J.I.N., Soni, H., Kumar, R.N., \& Bhatt, I. (2008). Macrophytes in phytoremediation of heavy metal contaminated water and sediments in Pariyej Community Reserve, Gujarat, India. Turkish Journal of Fisheries and Aquatic Sciences, 8(2): 193-200.

Kwon1, H.K., Jeon, J.Y., \& Oh, S.J. (2017). Potential for heavy metal (copper and zinc) removal from contaminated marine sediments using microalgae and light emitting diodes. Ocean Science Journal, 52(1): 57-66.

Lasheen M.R. \& Amma, N.S. (2014). Ex situ remediation technology for heavy metals in contaminated sediment. Desalination and Water Treatment, 52(7): 1-8.

Lee, G., Suonan, Z., Kim, S.H., Hwang, D.W., \& Lee, K.S. (2019). Heavy metal accumulation and phytoremediation potential by transplants the seagrass Zostera marine in the polluted bay system. Marine Pollution Bulletin, 149, 110509.

Lee, J. \& Park, J.W. (2013). Numerical investigation for the isolation effect of in situ capping for heavy metals in contaminated sediments. KSCE Journal of Civil Engineering, 17(6): 1275-1283.

Li, X., Dai, L., Zhang, C., Liu, Y., Zeng, G., Wu, Y., Tang, X., Liu, W., \& Lan, S. (2016). Enhanced biological stabilization of heavy metals in sediments using immobilized sulphate reducing bacteria beads with inner cohesive. Journal of Hazardous Materials, 324: 340-347.

Li, X., Wu, Y., Zhang, C., Liu, Y., Zeng, G., Tang, X., Dai, L., \& Lan, S. (2016). Immobilizing of heavy metals in sediments contaminated by nonferrous metals smelting plant sewage with sulphate bacteria and micro zero valent iron. Chemical Engineering Journal, 306: 393-400.

MacFarlane, G., Pulkownik, A., \& Burchett, M. (2003). Accumulation and distribution of heavy metals in the grey mangrove, Avicennia marina (Forsk) Vierh: biological indication potential. Enviromental Pollution, 123(1): 139-151.

Maldonando-Roman, M., Jimenez-Collazo, J., Malave-Llamas, K., \& MusaWasil, J.C. (2016). Mangroves and their response to a heavy metal polluted wetland in the north coastal of Puerto Rico. The Journal of Tropical life science, 6(3): 210-218.

Mohan, R.K., Brown, M.P., \& Barnes, C.R. (2000). Design criteria and theoretical basis for capping contaminated marine sediments. Applied Ocean Research, 22(2): 8593.

Mohanti, M. \& Mahindrakar, A.B. (2011). Removal heavy metal by screening followed by soil washing from contaminated soil. International 
Journal of Technology and Engineering System, 2(3): 290-293.

Mulligan, C.N., Yong, R.N., \& Gibbs, B.F. (2001). An evaluation of technologies for heavy metal remediation of dredged sediments. Journal of Hazardous Materials, 85(1-2): 145163.

Nguyen, V.K., Lee, M.H., Park, H.J., \& Lee, J.U. (2015). Bioleaching of heavy metals from mine tailing by pure and mixed cultures of Acidithiobacillus spp. Journal of Industrial and Engineering Chemistry, 21: 451-458.

Paz-Alberto, A.M. \& Sigua, G.C. (2013). Phytoremediation: a green technology to remove environmental pollutants. American Journal of Climate Change, 2(1): 71-86.

Park, Y.J., Ko, J.J., Yun, S.L., Lee, E.Y., Kim, S.J., Kang, S.W., Lee, B.C., \& Kim, S.K. (2008). Enhancement of bioremediation by Ralstonia sp. HM1 in sediment polluted by $\mathrm{Cd}$ and $\mathrm{Zn}$. Bioresource Technology, 99(16): 7458-7463.

Peng, J.F., Song, Y.H., Yuan, P., Cui, X.Y., \& Qiu, G.L. (2009). The remediation of heavy metals contaminated sediment. Journal of Hazardous Material, 161(2-3): 633-640.

Peng, W., Li, X., Lin, M., \& Fan, W. (2019). Microbiological analysis of cadmium-contaminated sediments during biostabilization with indigenous sulfate-reducing bacteria. Journal of Soils and Sediments.

Peng, W., Li, X., Xiao, S., \& Fan, W. (2018). Review of remediation technologies for sediments contaminated by heavy metals. Journal of Soils and Sediments, 18(4): 1701-1719.

Peng, W., Li, X., Liu, T., Liu, Y., Ren, J., \& Liang, D. (2018). Biostabilization of cadmium contaminated sediments using indigenous sulfate reducing bacteria: Efficiency and process. Chemosphere, 201: 697-707.
Perelo, L.W. (2010). Review: In situ and bioremediation of organic pollutants in aquatic sediments. Journal of Hazardous Materials, 177(1-3): 8189.

Qian, G., Che, W., Lim, T.T., \& Chui, P. (2009). In-situ stabilization of $\mathrm{Pb}, \mathrm{Zn}$, $\mathrm{Cu}, \mathrm{Cd}$ and $\mathrm{Ni}$ in the multicontaminated sediments with ferrihydrite and apatite composite additives. Journal of Hazardous Materials, 170(2-3): 1093-1100.

Ra, K., Kim, J.K., Hong, S.H., Yim, U.H., Shim, W.J., Lee, S.Y.... \& Kim, K.T. (2014). Assesment of pollution and ecological risk of heavy metals in the surface sediments of Ulsan Bay, Korea. Ocean Science Journal, 49(3): 279-289.

Rahman, M.S., Hossain, M.B., Babu, S.M. O.F., Rahman M., Ahmed, A.S.S., Jolly, Y.N.... \& Akter, S. (2019). Source of metal contamination in sediment, their ecological risk, and phytoremediation ability of the studied mangrove plants in ship breaking area, Bangladesh. Marine Pollution Bulletin, 141: 137-146.

Rosado, D., Usero, J., \& Morillo, J. (2016). Assessment of heavy metals bioavailability and toxicity toward Vibrio fischeri in sediment of the Huelva estuary. Chemosphere, 153: 10-17.

Saher, N.U. \& Siddiqui, A.S. (2019). Occurrence of heavy metals in sediment and their bioaccumulation in sentinel crab (Macrophthalmus depressus) from highly impacted coastal zone. Chemosphere, 221: 8998.

Sakakibara, M., Ohmori, Y., Ha, N.T.H., Sano, S., \& Sera, K. (2011). Phytoremediation of heavy metalcontaminated water and sediment by Eleocharis acicularis. Clean-Soil, Air, Water, 39(8): 735-741.

Sfakianakis, D.G., Reinieri, E., Kentouri, M., \& Tsatsakis, A. M. (2015). Effect of heavy metals on fish larvae 
deformities: A review. 2015. Environmental Research, 137: 246255.

Shahid, M., Austruy, A., Echevarria, G., Arshad, M., Sanaullah, M., Aslam, M., Nadeem, M., Nasim, W., \& Dumat, C. (2014). EDTA-enhanced phytoremediation of heavt metals: A Review. Soil and Sediment Contamination, 23(4): 389-416.

Shin, W. \& Kim, Y.K. (2015). Stabilization of heavy metal contaminated marine sediments with red mud and apatite composite. Journal of Soils and Sediments, 16(2): 726-735.

Singh, J., \& Kalamdhad, A.S. (2011). Effect of heavy metals on soil, plants, human health and aquatic life. International Journal of Research in Chemistry and Environmen, 1(2): 1521.

Song, B., Zeng, G., Gong, J., Liang, J., Xu, P., Liu, Z. .... \& Ren, X. (2017). Evaluation methods for assessing effectiveness of in situ remediation of soil and sediment contaminated with organic pollutants and heavy metals. Enviromental International, 105: 4355.

Tabak, H.H., Lens, P., van Hullebusch, E.D., \& Dejonghe, W. (2005). Developments in bioremediation of soils and sediments polluted with metals and radionuclides- 1 . Microbial processe and mechanisms affecting bioremediation of metal contamination and influencing metal toxicity and transport. Review in Environmental Science and Biotechnology, 4(3): 115-156.

Tangahu, B.V., Abdullah, S.R.S., Basri, H., Idris, M., Anuar, N., \& Mukhlisin, M. (2011). A Review on heavy metals (As, $\mathrm{Pb}$, and $\mathrm{Hg}$ ) uptake by plants through phytoremediation. International Journal of Chemical Engineering, 2011: 1-31.

Tsezos, M. 2009. Metal-microbes interaction: beyond environmental protection. Advance Material Research, 71-73: 527-532.

Vandecasteele, B., Samyn, J., Quataert, P., Muys, B., \& Tack, F. M. G. (2004). Earthworm biomass as additional information for risk assessment of heavy metal biomagnification: a case study for dredged sediment-derived soils and polluted floodplain soils. Environmental Pollution, 129(3): 363-375.

Vu, C.T., Lin, C., Shern, C.C., Yeh, G., Le, V.G., \& Tran, H.T. (2017). Contamination, ecological risk and source apportionment of heavy metals in sediments and water of a contaminated river in Taiwan. Ecological Indicators, 82: 32-42.

Wan, J., Zeng, G., Huang, D., Hu, L., Xu, P., Huang, C., ..... \& Gong, X. (2017). Rhamnolipid stabilized nanochlorapatite: Synthesis and enhancement effect on $\mathrm{Pb}$ - and $\mathrm{Cd}$ immobilization in polluted sediment. Journal of Hazardous Materials, 343: 332-339.

Wang Y., Qiu, Q., Xin, G., Yang, Z., Zheng, J., Ye, Z., \& Li, S. (2012): Heavy metal contamination in a vulnerable mangrove swamp in South China. Environmental Monitoring and Assessment, 185: 5775-5787.

Yin, H. \& J. Zhu. (2016). In situ remediation of metal contaminated lake sediment using naturally occurring, calcium-rich clay mineral based low cost amendment. Chemical Engineering Journal, 285: 112-120.

Yoo, J.C., Lee, C.D., Yang, J.S., \& Baek, K. (2013). Extraction characteristics of heavy metals from marine sediments. Chemical Engineering Journal, 228: 688-699.

Zhang, C., Zhu, M.Y., Zeng, G.M., Yu, Z. G., Cui, F., Yang, Z.Z., \& Shen, L.Q. (2016). Active capping technology: a new environmental remediation of contaminated sediment. Environmental Science and Pollution Research, 23(5): 4370-4386. 
Zhang, Z., Li, M., Chen, W., Zhu, S., Liu, N., \& Zhu, L. (2010). Immobilization of lead and cadmium from aqueous and contaminated sediment using nano-hydroxyapatite. Enviromental Pollution, 158(2): 514-519.

Zhu, C.Q., Ghoto, K., Gao, G.F., Chen, J., Hu, W.J., Qiao, F., Liu, J.Y., \& Zheng, H.L. (2019). Trace metal complexation behaviour with root exudates induced by salinity from a mangrove plant Avicennia marina
(Forsk.) Vierh. Bioremediation journal, 1-2.

Zhu, J.Y., Zhang, J.X., Li, Q., Han, T., Hu, Y.H., Liu, X.D., Qin, W.Q., Chai, L.Y., \& Qiu, G.Z. (2014). Bioleaching of heavy metals from contaminated alkaline sediment by auto- and heterotrophic bacteria in stirred tank reactor. Transaction of Nonferrous Metals Society of China, 24(9): 2969-2975. 